\title{
Views of the Students Learning Turkish as a Foreign Language on Distance Education during the COVID-19 Pandemic
}

\author{
Nurettin KARTALLIOĞLU* \\ Turkish Language Department, Bolu Abant Izzet Baysal University, Bolu, Turkey. \\ ORCID: 0000-0002-3464-8716
}

Article history

Received:

04.09.2021

Received in revised form: 10.12.2021

Accepted:

10.12.2021

Key words:

Teaching Turkish as a foreign language, teaching Turkish to foreigners via distance education, language teaching during the COVID-19 pandemic.
This study examines the views of international students learning Turkish as a foreign language (TFL)through distance education during the COVID-19 pandemic. The study is qualitative by nature and employed the case study method. The study group consisted of 31 nationals from different countries who had to take preparatory TFL courses in order to qualify as undergraduate students at the faculty of Engineering of the Bolu Abant Izzet Baysal University during the 2019-2020 academic year. A semi-structured interview form was used to determine the views of the participating foreign students on distance education during the pandemic. The results showed a decline in the expected language levels of the students due to technology and education-related problems they experienced during their distance learning process. While the students expressed the positive aspects of distance education as protection from the virus, recording of the classes which allowed repeated viewing, gaining experience, and saving time; the negative aspects expressed by the students were lack of previous experience in distance education, feelings of isolation, and having trouble asking for clarification when a teaching point was not understood during classes. More than half of the students stated that their motivation had increased during distance education and that they reported improvement in all their language skills but speaking. While the TFL students expressed positive opinions about online exams stating that they experienced less exam stress and did not have to go to school to take them, they also mentioned negative aspects of those exams such as technical problems they experienced while taking the exams and a high likelihood of cheating. Suggestions were made by the researcher based on the findings.

\section{Introduction}

Throughout history, humanity has faced various disasters such as earthquakes, floods, fires, wars, and epidemics. Although these disasters were somehow warded off over time, these dismal events that deeply affected humanity changed the world at times. Today, humanity is struggling with the COVID-19 pandemic, which is affecting the whole world.

The pandemic first appeared in the city of Wuhan, China, towards the end of 2019. This virus is thought to have been transmitted from animals to humans. The disease spread all over the world in a short time. Revealing the seriousness of the situation, the World Health

\footnotetext{
*Correspondency: kartallioglu_n@ibu.edu.tr
} 
Organization (WHO) declared the COVID-19outbreak a global pandemic on March 11, 2020, (Turkish Academy of Sciences, 2020). All areas involving intense human interaction, especially, economy, health, sports, tourism, and education, have been adversely affected by the pandemic. People's lifestyles and daily habits have changed completely as they try to adapt to these unprecedented developments in their lives. It is currently unclear as to when the disease will dissipate.

The presence of COVID-19 was confirmed in Turkey with the detection of the first case on March 11, 2020. After the case was confirmed, various measures were taken in almost every aspect of life to prevent the spread of the virus in the country. One of those measures was to close schools and various educational institutions temporarily to adapt rapidly to changing conditions. The Council of Higher Education (CoHE) acted accordingly and advised universities to continue the Spring semester of the 2019-2020 academic year through distance education to minimize the effects of any pandemic-related negative developments and to ensure the continuation of educational activities (CoHE, 2020). Effective March 23, 2020, universities have switched to distance education. Since then, millions of students have started taking courses through distance education regardless of their experience in distance education.

Distance education in which students and faculty members are in various locations and settings during teaching and learning activities (Kaya, 2002; Uşun, 2006; Yalın, 2003) is an educational practice that ensures flexibility with regard to age, purpose, time, and place (Uşun, 2006) and utilizes technological tools in the learning-teaching process (Uşun, 2006; Yalın, 2001).This practice is, in essence, an internet-based learning method where teachers and students interact outside actual classrooms (Dabbagh \& Brenda, 2005; Farrah \& AlBakry, 2020; Özaygen, 2000). In this sense, distance education provides people with individual learning opportunities and offers greater flexibility when compared with traditional education (İşman, 2011).

Based on the previous definitions and implementations, Keegan (1996) expressed the basic characteristics of distance education as follows:

- The separation of students and teachers during the learning process,

- The design of learning environments and the teaching process by the institution,

- The existence of two-way communication between the teacher and students and students themselves,

- The use of media and technology for the interaction between the teacher and students and students themselves, and

- The quasi-permanent absence of learning groups to enhance social and individual learning.

Thus, for a course to be successfully conducted through distance education and to reveal its benefits or limitations, it should be developed in line with the features listed by Keegan above (1996).

Distance education has several advantages such as providing lifelong learning opportunities, having a very stimulating learning environment and flexibility in terms of methods and techniques that can be used, providing equal opportunities in education, giving students the opportunity to watch the recorded classes again, and being independent in terms of time and venue (Uşun, 2006). Additionally, the benefits of distance education are individualizing teaching, reducing teaching costs, providing quick access to the teaching of new subject areas, 
and bringing new standards to education (Gürer, 2021).

While distance education has advantages, it also comes with limitations such as disconnection problems that may occur at any point during a class, difficulties students who do not have strong individual learning habits experience in understanding classes, limited communication between teachers and students, and the lack of various technological infrastructures essential for the successful implementation of distance education (Nenko, Kybalna, \& Snisarenko, 2020; Tirtanawati, 2021; Uşun, 2006; Yanpar, 2009). It has also been determined that distance education is not suitable for the development of psycho-motor skills and is not as effective as face-to-face education in providing social interaction among students. The lack of experience of teachers in distance education is also one of the factors affecting the success of distance education (Gürer, 2021).

When the COVID-19outbreak was declared a global pandemic, all educational institutions had to switch to distance education rapidly and in an unplanned manner in order to continue the education process. This unexpected transformation in education has brought some problems (Alan, Biçer, \& Can, 2020; Erzen \& Ceylan, 2020; Farrah \& Al-Bakry, 2020). These problems have been experienced in foreign language education at higher levels. According to Hurd (2006), learning a foreign language through distance education is more difficult than learning most subjects. Although distance education tools and applications are not new in language education, they pose a challenge in terms of student interaction (Payne, 2020). Language education is first and foremost related to teaching skills. In distance education, students are expected to learn the language through the use of various applications and use it effectively in situations they are exposed to. There are studies (Ahmad, 2016; Doğan, 2020; Mahibur Rahman, 2020) that show that the desired outcomes may not be achieved in the teaching of basic language skills which are the main elements of language. The forced transition to compulsory distance education brings with it some opportunities as well. Therefore, it is very important to determine what does not work in this process and the problems that arise (Carrillo \& Flores, 2020) in order to effectively plan the ensuing processes.

Various studies on distance foreign language education during the pandemic are available in the professional literature. However, the number of studies investigating foreign language education at the university level is limited. In one such study, Farrah and Al-Bakry (2020) aimed to determine the views of Palestinian EFL students on distance education. They concluded that the Palestinian EFL students regarded distance education to be positive because it increased their self-confidence, encouraged them to do research in their learning, allowed them to improve themselves in terms of technology, and offered them different experiences. The negative aspects of distance education reported in the study were insufficient technological infrastructure and the unreliability of the exams. The students in the study expressed an overall positive opinion about distance education. In another study, Mahibur Rahman (2020) conducted a survey among lecturers teaching at three universities in Saudi Arabia to determine the difficulties they experienced in distance foreign language education. In the study, the majority of foreign language teachers reported that face-to-face education was better than distance education and that student motivation in distance education was not high. In another study, Öztürk Karataş and Tuncer (2020) determined that during foreign language teaching through distance education, in terms of the four basic language skills, students had the most advantage in writing and the least advantage in speaking. They also reported that various writing assignments given by the teacher helped develop students' writing skills while the speaking skill was more neglected. 
Hernández and Flórez (2020) conducted a study with twenty-two English teachers in Colombia and reported that the participants believed that synchronous encounters positively impacted the students' motivation levels because they allowed interaction and providing guidance and feedback in real-time. Similarly, Atmojo and Nugruho (2020) interviewed sixteen foreign language teachers in Indonesia to identify successful distance foreign language education practices and challenges. The teachers who participated in the research stated that communication between teachers and students was very important in the learning process and that the emotional bond between teachers and students could not be strengthened due to the lack of communication and interaction in distance education. In a study with university students learning English in Saudi Arabia, Mahyoob (2020) intended to determine the difficulties of e-learning and concluded that, problems experienced by the students could be grouped under three categories as technical, academic, and communication difficulties. In addition, the students reported that they could not achieve the success they had targeted and were not satisfied with distance education. The study by Famularsih (2020) is another scholarly endeavor to determine university-level ESL students' experiences in Indonesia; the results of the study showed that students approached distance education positively during the epidemic. Although internet-related problems emerged during the distance education process, the students' reading and writing skills improved while their speaking and listening skills failed to reach the desired level. Karakış (2020) aimed to identify university students' achievement in English courses and their views on distance learning environments and reported that students had positive views on the distance education environment regardless of their achievement levels. The study conducted by Tirtanawati (2021) determined that students had problems related to the internet during the distance education process and that they were bored with distance education course activities and missed face-to-face education. Allo (2020) reported that foreign language learners had positive perceptions towards distance education, but they experienced internet connection problems and financial problems. Aryanti (2020) listed the problems experienced by Indonesian university students learning English in distance education as internet connection problems, problems arising from the use of online applications, and health problems due to constantly looking at technological devices such as computers, tablets, and mobile phones.

Efriana (2021) examined the problems that occurred in distance foreign language education from the perspectives of teachers, students, and parents. The problems experienced by the teachers were the lack of technological know-how and problems in student supervision; the problems experienced by the students were the inability to follow the course and problems regarding the internet, and the problems experienced by the parents were the inability to pay sufficient attention to their children and to help them during online courses. The study conducted by Rahman (2020) reported that university students learning a foreign language perceived distance education as beneficial during the epidemic. It was observed that the students experienced difficulties in understanding some course materials, had internet connection problems, and encountered technical problems.

Previous studies mostly focused on problems such as internet connection problems and problems related to insufficient technological infrastructure. However, technological problems form a part of the issues that negatively affect distance language education. The subject should, therefore, be handled holistically by focusing on other significant elements of language teaching. Hence, this study aimed to investigate the factors such as teaching four basic language skills, evaluation of basic language skills, positive and negative aspects of distance education classes, problems experienced during distance education, and student motivation, all of which play a major role in teaching TFL via distance education. Thus, this 
study set out to explore the role of those factors in distance foreign language education.

The main question of the study was "What are the views of the international students who are learning Turkish as a foreign language on distance education during the COVID-19 pandemic?" which could be answered by obtaining the participants' responses to the following nine sub-questions that will provide information to answer the main research question:

(1) What problems have the students experienced while taking Turkish classes during the pandemic?

(2) Do the students think there has been an improvement in their language skills during the pandemic?

(3) What are the positive and negative aspects of the Turkish classes provided via distance education during the pandemic?

(4) How has the pandemic affected the students' level of active participation and motivation in Turkish classes?

(5) How has the pandemic affected the development of the students' reading skills?

(6) How has the pandemic affected the development of the students' listening skills?

(7) How has the pandemic affected the development of the students' speaking skills?

(8) How has the pandemic affected the development of the students' writing skills?

(9) What are the positive and negative aspects of online exams conducted to determine students' Turkish proficiency levels during the pandemic?

\section{Method}

\section{Research Model}

This study utilized the case study design to determine the views of the TFL students regarding their distance education experiences during the COVID-19 era. Case study is an indepth analysis of an individual situation such as a person, group, event, or phenomenon in detail (Büyüköztürk, Çakmak, Akgün, Karadeniz \& Demirel, 2016) with the intention to explore, describe and interpret that person, group, event, or phenomenon in its unique environment (Christensen, Johnson, \& Turner, 2015; Creswell, 2013; Paker, 2017). Case study research is commonly used in language learning, first language and second language acquisition, and teacher education studies. It was used in this study to capture and analyze the views of TFL students on the distance education process and to evaluate the process in detail.

\section{Study Group}

The study group consisted of 31 international students, studying at the Bolu Abant Izzet Baysal University, Faculty of Engineering and learning Turkish as a foreign language in the preparatory program of the Turkish education center of the university in the 2019-2020 academic year. Criterion sampling was used to form the study group. Two criteria were identified before the research: voluntary participation and regular attendance in the distance education classes. Table 1 presents the descriptive information about the study group. 
Table 1. Descriptive information about the study group

\begin{tabular}{|c|c|c|c|}
\hline Variable & Categories & f & $\%$ \\
\hline \multirow{15}{*}{ Country } & Syria & 8 & 25.81 \\
\hline & Iraq & 4 & 12.90 \\
\hline & Azerbaijan & 3 & 9.68 \\
\hline & Palestine & 3 & 9.68 \\
\hline & Afghanistan & 2 & 6.45 \\
\hline & Morocco & 2 & 6.45 \\
\hline & Yemen & 2 & 6.45 \\
\hline & Pakistan & 1 & 3.23 \\
\hline & Uzbekistan & 1 & 3.23 \\
\hline & Bangladesh & 1 & 3.23 \\
\hline & Cameroon & 1 & 3.23 \\
\hline & Mali & 1 & 3.23 \\
\hline & Mauritania & 1 & 3.23 \\
\hline & Kenya & 1 & 3.23 \\
\hline & Total & 31 & 100 \\
\hline \multirow{3}{*}{ Gender } & Female & 7 & 22.58 \\
\hline & Male & 24 & 77.42 \\
\hline & Total & 31 & 100 \\
\hline \multirow{4}{*}{ Age } & $17-21$ & 28 & 93.55 \\
\hline & $22-26$ & 1 & 3.23 \\
\hline & $27+$ & 1 & 3.23 \\
\hline & Total & 31 & 100 \\
\hline \multirow{3}{*}{ Distance Education Experience } & Yes & 2 & 6.45 \\
\hline & No & 29 & 93.55 \\
\hline & Total & 31 & 100 \\
\hline \multirow{2}{*}{ Level of Turkish } & $\mathrm{C} 1$ & 31 & 100 \\
\hline & Total & 31 & 100 \\
\hline
\end{tabular}

Table 1 demonstrates that the students were from 14 different countries. Of those participants, eight were Syrian, four were Iraqi, three were Azerbaijani, and three were Palestinian. There were two students from each of the countries of Afghanistan, Morocco, and Yemen. There was one student from each of the countries of Pakistan, Uzbekistan, Bangladesh, Cameroon, Mali, Mauritania, and Kenya.

Seven students $(22.58 \%)$ were female and $24(77.42 \%)$ were male. Twenty-nine students $(93.55 \%)$ were between the ages of $17-21$, one $(3.23 \%)$ was between the ages of $22-26$ and one $(3.23 \%)$ was 27 years or older. Only two $(6.45 \%)$ students had prior distance education experience. The remaining $29(93.55 \%)$ students did not have such experience. All students had C1 level Turkish proficiency.

\section{Data Collection Tool}

A semi-structured interview form was used in the study to determine the views of the TFL students on distance education during the COVID-19 pandemic. An interview form with 10 questions was developed by the researcher after reviewing the relevant literature. Expert opinion was sought for the interview questions from two experts working in the field of Turkish education and one expert working in the field of assessment and evaluation. Upon the feedback received from the experts and establishing content validity, the resulting interview form included 10questions. A pilot study was conducted with five TFL students to determine whether the questions in the interview form were clear and comprehensible. At the end of the 
analysis of the pilot study findings, the interview form was finalized by making necessary changes based on student feedback received in the pilot study.

\section{Data Collection}

An application was made to the ethics committee of the university for data collection. The study was approved by the Bolu Abant Izzet Baysal University Human Research Ethics Committee (Protocol No. 2020/303) on December 24, 2020. Since face-to-face interviews with the participants would be allowed due to the COVID-19 pandemic, Google Forms was used to make the interview form available on digital media. Afterward, the digital interview form was sent to the students' e-mail addresses. The data were obtained through the responses of the students who voluntarily participated in the study.

\section{Data Analysis}

Content analysis was used to analyze the data. Content analysis is a systematic, repeatable technique in which the ideas in a text are summarized in smaller content categories with coding based on certain rules. With this technique, inferences are made by identifying certain features in a set of data objectively and systematically (Büyüköztürk et al., 2016: 250). The aim is to reveal the facts that may be hidden in the data (Cohen, Manion \& Morrison, 2007; Y1ldırım \& Şimşek, 2016). Prior to the analysis, the participants were coded as P1, P2, P3 to ensure their privacy and adhere to ethical research principles.

During data analysis, the researcher identified themes according to the research questions. Codes were created from the students' answers to each question. Sub-themes with similar content were formed and included under the relevant themes. Direct quotations were used to support the findings.

\section{Validity and Reliability}

To establish the content validity of the form, firstly, the opinions of two experts working in the field of Turkish education and an expert working in the field of measurement and evaluation were sought to check whether the prepared questions covered the subject to be investigated and whether the questions were intelligible. Based on expert opinions, necessary revisions were made in the questions to improve content validity.

The revised interview form was used in a pilot study. The results of the pilot interviews conducted with a similar group of students showed that the feedback given by the students was also positive. The form was then given its final shape based on this feedback. The final form was examined by an expert in the field of Turkish education and found to be fit for the purpose of the study.

To calculate reliability, the formula (Reliability $=$ consensus/consensus + disagreement $\mathrm{X}$ 100) developed by Miles and Huberman (1994) was chosen. The data would be collected and coded separately by two field experts and would be compared for inter-rater reliability. The themes identified by the experts were compared with the themes identified by the researcher, and it was determined that the themes were $90 \%$ compatible. This finding showed that the obtained results were reliable. 


\section{Findings}

The findings obtained in the interviews with the participating students were collected under nine main themes. Sub-themes and codes will be provided under each theme.

\section{Findings regarding the Problems Students have Experienced while Taking Distance Turkish Classes during the COVID-19 Pandemic}

Table 2 presents the sub-themes and the codes formed based on the student responses to the following question: "What problems did you experience while taking Turkish classes during the COVID-19 pandemic?"

Table 2. Problems experienced by the students while taking distance Turkish classes

\begin{tabular}{lll}
\hline Sub-Themes & Code & F \\
\hline \multirow{2}{*}{ Problems Related to Technology } & Internet connection problems & 16 \\
& Lack of technological devices & 6 \\
& System-related Problems & 4 \\
\hline \multirow{2}{*}{ Problems Related to Education } & Inability to focus on online courses & 5 \\
\hline
\end{tabular}

The problems experienced by the students could be summarized under the 2 sub-themes given in Table 2. Regarding the problems related to technology, it was found that the students mostly experienced internet connection problems $(f=16)$, that they did not have technological devices $(f=6)$, and that they had system-related problems $(f=4)$. Some of the students' views on technology-related problems are presented below:

P4: "I have been taking online education classes in the coronavirus process. I have had some technology-related problems in this period. Sometimes I could not attend the classes due to internet connection problems which caused me to regress a little."

P16: "Not having a computer was my biggest problem. My computer was in another city and my father couldn't send it to me."

P17: "I had a hard time adapting to the new system during the COVID-19 period. It was difficult to access online education and the system was confusing."

Regarding problems related to education, it was determined that the students could not focus on online classes $(f=5)$. This lack of focus negatively affected their active participation in classes. Regarding this issue, one student expressed his view as follows:

P29: "I couldn't focus on the lesson as much as I wanted because something was constantly distracting me since it was online."

\section{Findings regarding the Effects of the COVID-19 Pandemic on the Development of the Students' Turkish Language Skills}

Table 3presents the sub-themes and the codes formed based on the student responses to the following question: "Do you think there has been an improvement in your language skills during the pandemic?" 
Table 3. Status of the students' Turkish skills during the covid-19 pandemic

\begin{tabular}{lll}
\hline Sub-Themes & Code & F \\
\hline \multirow{3}{*}{ No improvement in skills } & Lack of practice & 12 \\
& Challenges posed by distance education & 3 \\
& Problems related to recall & 2 \\
\hline \multirow{3}{*}{ Improvement in skills } & Watching Turkish TV series and movies & 7 \\
& Creating Practice opportunities & 4 \\
& Adapting to distance education & 3 \\
\hline
\end{tabular}

Student views about the changes in their Turkish skills were summarized under 2 sub-themes. The first sub-theme titled No improvement in skills included lack of practice $(f=12)$, challenges posed by distance education $(f=3)$, and problems related to recall $(f=2)$ as reasons. The views of some students who observed no improvement in their Turkish skills are as follows:

P7: "My Turkish has not improved because I am not able to practice Turkish and have faceto-face conversations with my Turkish friends."

P16: "My Turkish level has not improved because distance education was not as beneficial as face-to-face education. I was spending time with my friends before the epidemic, and we were improving our Turkish language skills together because we spoke Turkish all the time."

P11: "I started to forget the words I knew and didn't know what to do."

The sub-theme Improvement in skills included watching Turkish TV series and movies $(f=7)$, creating practice opportunities $(f=4)$, and adapting to distance education $(f=3)$ as reasons. That some students intended to prevent such a highly probable lack of improvement in language skills in the face of the epidemic indicated a positive attitude and determination to hone their Turkish skills on their part.

P23: "As I have been speaking Turkish with my Turkish friends whenever I can and watching Turkish TV series and movies, I have not experienced any decline in my Turkish skills."

P13: "I did not experience any decline because I have been meeting with my friends and speaking Turkish."

\section{Findings regarding the Positive and Negative Aspects of Online Turkish Classes during the COVID-19 Pandemic}

Table 4 presents the sub-themes and the codes formed by student responses to the following question: "In your opinion, what are the positive and negative aspects of Turkish classes taught via distance education during the COVID-19 pandemic?" 
Table 4. Positive and negative aspects of online Turkish classes taken during the covid-19 pandemic

\begin{tabular}{lll}
\hline Sub-Themes & Code & F \\
\hline & Protection from the virus & 12 \\
Positive aspects & Recorded lectures & 9 \\
& Gaining distance learning experience & 6 \\
& Saving time & 4 \\
\hline & Lack of practice & 20 \\
Negative aspects & Comprehension difficulties & 7 \\
& Being away from teachers and friends & 2 \\
& Not being able to ask questions on the spot & 2 \\
\hline
\end{tabular}

Students' views on the positive aspects of online Turkish classes were as follows: Protection from the $\operatorname{virus}(f=12)$, recorded lectures $(f=9)$, gaining distance learning experience $(f=6)$, and saving time $(f=4)$. The views of some students regarding the positive aspects of distance Turkish lessons are below:

P1: "Receiving distance education has become a necessity, especially due to COVID-19. Distance education has helped us protect ourselves from this disease."

P5: "We were able to connect to the lectures wherever there was an internet connection. The good thing was that we had the chance to watch the lectures as many times as we needed because it was recorded."

P4: "Distance education was a necessity. Thanks to distance education, we were able to access the classes and course materials very easily and quickly. This was a good experience for us."

P16: "Since I attended the classes at home, I did not lose any time going to school. This gave me more free time. I read a lot of Turkish books in my free time."

Students' views on the negative aspects of distance Turkish lessons were as follows: lack of practice $(f=20)$, difficulty in understanding $(f=7)$, being away from teachers and friends $(f=2)$, and not being able to ask questions on the spot $(f=2)$. The views of some students regarding the negative aspects of distance Turkish lessons are below:

P25: "If we had face-to-face education, we would practice Turkish more. Unfortunately, due to the pandemic, this is currently not possible at all".

P31: "Distance education is unlike face-to-face education. We have difficulties in comprehension. I hope that when the pandemic ends, we will start face-to-face education."

P2: "Not being together with teachers and friends made education even more difficult. If we had been together, we could have been more successful."

P8: "I can't ask about a point I don't understand right away as I can in a face-to-face class. By the time I write or speak, the teacher usually has already moved ahead."

\section{Findings regarding the Effective Participation Levels and Motivation of Students in Turkish Classes during the COVID-19 Pandemic}

Table 5 presents the sub-themes and the codes formed based on student responses to the following two-part question: "Has the COVID-19 pandemic increased or decreased your 
level of active participation and motivation in Turkish classes? How has it affected your participation?"

Table 5. Students' active participation and motivation in online Turkish classes

\begin{tabular}{lll}
\hline Sub-Themes & Code & f \\
\hline \multirow{2}{*}{ Increase inactive participation and motivation } & Teachers' attitudes & 9 \\
& Desire to learn & 8 \\
\hline \multirow{2}{*}{ Decrease inactive participation and motivation } & Inability to concentrate & 8 \\
& Feelings of loneliness & 6 \\
\hline
\end{tabular}

The students who stated that their participation levels and motivation increased in online Turkish classes cited the attitudes of teachers $(f=9)$ and the desire to learn $(f=8)$ as factors that led to the increase. The views of some students who stated that their participation and motivation in Turkish classes increased during this period are below:

P1: "Since our teacher is very good and understanding, I attend the Turkish classes with pleasure. This increases my motivation towards the lesson."

P7: "I was positively affected because I saw them as a great opportunity for achievement. We were having an exceptional year, and I wanted to make the best of it."

The students who stated that their participation level and motivation decreased in the online Turkish classes cited the inability to concentrate $(f=8)$ and feelings of loneliness $(f=6)$ as their reasons. The views of some students who stated that their participation and motivation in Turkish classes decreased during this period are below:

P3: "My motivation to attend Turkish lessons decreased because I did not like and enjoy distance education. Also, because I had various other problems, my motivation decreased."

P11: "It was boring to study alone. Sitting alone in front of the screen, my motivation decreased, and I did not attend the classes."

\section{Findings on Students' Reading Skills during the COVID-19 Pandemic}

Table 6presents the sub-themes and the codes formed based on the student responses to the following two-part question: "Has the COVID-19 pandemic affected your reading skills? Has there been an improvement in your reading skills?"

Table 6. Student views on their reading skills during the covid-19 pandemic

\begin{tabular}{lll}
\hline Sub-Themes & Code & f \\
\hline \multirow{2}{*}{ Improvement in reading skills } & Making use of free time & 14 \\
& Reading different kinds of books & 9 \\
\hline \multirow{2}{*}{ No improvement in reading skills } & Not doing reading exercises & 5 \\
& Spending too much time on the Internet & 3 \\
\hline
\end{tabular}

The students who stated that their reading skills improved cited making use of free time $(f=$ $14)$ and reading different kinds of books $(f=9)$ as reasons. The views of some students who reported an increase in their reading skills are below:

P4: "I thought that I should do some activities because the lessons were online, and I was at home every day. I had a lot of free time. I had to make use of it somehow. During this period, I both attended classes and started to read some books outside of class. This is how COVID19 has improved my reading skills." 
P5: "I have read many novels and magazines during the pandemic. Thus, my reading has improved a lot. Apart from that, I have done a lot of reading exercises on various websites on the Internet."

The students who stated that there was no improvement in their reading skills cited not doing reading exercises $(f=5)$ and spending too much time on the Internet $(f=3)$ as their reasons. The views of some students are below:

P10: "My reading skills did not improve because I didn't do much reading practice. I didn't want to read books outside of class."

P23: "The pandemic has negatively affected my reading level because instead of reading in my spare time, I watched videos on the Internet."

\section{Findings on Students' Listening Skills during the COVID-19 Pandemic}

Table 7 presents the sub-themes and the codes formed by student responses to the following two-part question: "How has the COVID-19 pandemic affected your listening skills? Has there been an improvement in your listening skills?”

Table 7. Student views on their listening skills during the covid-19 pandemic

\begin{tabular}{lll}
\hline Sub-Themes & Code & f \\
\hline \multirow{2}{*}{ Improvement in listening skills } & Watching Turkish series and movies & 15 \\
& The effect of classes & 8 \\
\hline No improvement in listening skills & Lack of interaction & 8 \\
\hline
\end{tabular}

The students who stated that their listening level improved cited watching TV series and movies $(f=15)$ and the effect of classes $(f=8)$ as reasons. The views of some students who stated that their listening level improved are below:

P3: "I can say that my listening has improved during the COVID-19 pandemic because I started to watch Turkish movies and series and understand Turkish better now."

P20: "My listening has improved because, as a foreign student, I listen to the lecture videos over and over again."

The students who stated that there was no improvement in their listening skills cited lack of interaction $(f=8)$ as the reason. Below is a student's view:

P25: "The COVID-19 pandemic has caused a decline in my listening level and affected me negatively. When we were at school, we heard people speaking Turkish around us all the time, but we only listen to our teacher in distance education."

\section{Findings on Students' Speaking Skills during the COVID-19 Pandemic}

Table 8 presents the sub-themes and the codes formed based on the students' responses to the following two-part question: "How has the COVID-19 pandemic affected your level of speaking? Has there been an improvement in your speaking skills?" 
Table 8. Student views on their speaking skills during the covid-19 pandemic

\begin{tabular}{lll}
\hline Sub-Themes & Code & f \\
\hline Improvement in speaking skills & Individual efforts & 6 \\
\hline No improvement in speaking skills & Isolation & 25 \\
\hline
\end{tabular}

The students who stated that their speaking skills improved cited individual efforts $(f=6)$ as the reason. Below is a student's view:

P8: "I made some Turkish friends when I felt that my speaking skills were declining. They helped me practice Turkish one day a week."

The students who stated that there was no improvement in their speaking skills cited isolation $(f=25)$ as the reason. Below is a student's view regarding the decline in her speaking skills:

P10: "My speaking ability has declined since we stayed at home, did not leave the house, could not communicate with people, and could not talk to them. Speaking also decreased a lot during classes. The teacher talks and explains; we just listen."

\section{Findings on Students' Writing Skills during the COVID-19 Pandemic}

Table 9 presents the sub-themes and the codes formed based on the students' responses to the following two-part question: "How has the COVID-19 pandemic affected your writing skills? Has there been an improvement in your writing skills?"

Table 9. Student views on their writing skills during the covid-19 pandemic

\begin{tabular}{|c|c|c|}
\hline Sub-Themes & Code & $\mathbf{f}$ \\
\hline \multirow{3}{*}{ Improvement in writing skills } & Writing assignments & 9 \\
\hline & Technological support & 4 \\
\hline & Extracurricular studies & 4 \\
\hline \multirow{2}{*}{ No improvement in writing skills } & Dislike for writing & 8 \\
\hline & No need for writing & 6 \\
\hline
\end{tabular}

The students who stated that their writing level improved in Turkish classes cited writing assignments $(f=9)$, technological support $(f=4)$, and extracurricular studies $(f=4)$ as reasons. The views of some students who stated that their writing level improved in Turkish classes during this period are below:

P4: "My writing has improved. There were reports that we had to prepare in the classes we attended. Therefore, I think that my writing did not decline; on the contrary, it improved."

P18: "My writing skills have improved a lot because I read a lot and wrote what I understood. I learned new words and learned how to use them over time. I improved myself like I had never done before. This has been very beneficial for my writing skills."

P21: "After the classes, I did some writing by myself. It was very difficult at first; but I started writing easily after a while."

The students who stated that there was no improvement in their writing skills cited dislike for writing $(f=8)$ and no need for writing $(f=6)$ as reasons. The views of some students who stated that their writing level declined are below:

P16: “I haven't written much during this time. I like reading and listening more. There is 
nothing to motivate me to write."

P23: "My writing has been negatively affected. I haven't felt the need to write because I have been talking to my classmates and Turkish friends on the phone."

\section{Findings regarding Online Exams during the COVID-19 Pandemic}

Table 10 presents the sub-themes and the codes formed based on the students' responses to the following question: "What are the positive and negative aspects of online exams conducted to assess your Turkish level during the COVID-19 pandemic?

Table 10. Student views on online exams during the covid-19 pandemic

\begin{tabular}{lll}
\hline Sub-Themes & Code & F \\
\hline \multirow{2}{*}{ Positive aspects } & No exam stress & 10 \\
& No obligation to go to school & 4 \\
\hline \multirow{2}{*}{ Negative aspects } & Internet connection problems & 8 \\
& Bottlenecks in the system & 5 \\
& Inability to ask teachers questions & 2 \\
\hline
\end{tabular}

The students who mentioned positive aspects of online exams cited no exam stress $(f=10)$ and no obligation to go to school $(f=4)$ as reasons. The views of some students who had positive views about taking exams online are below:

P26: "I was very comfortable during online exams; I did not experience any stress. There was no teacher, no friends. We take exams comfortably. That's why online exams are very good."

P5: "Even if you are sick, you can still take the exam; there is no need to go to school. For example, I was sick during the exam, and I took the exam in my bed. If the exam had been face-to-face, I would not have been able to take the exam."

The students who reported negative aspects of online exams cited internet connection problems $(f=8)$, bottlenecks in the system $(f=5)$, inability to ask questions during the exam $(f=2)$, and cheating $(f=2)$ as reasons. The views of some students who had negative views about taking exams online are below:

P3: "Being frequently disconnected while answering questions is a big problem."

P20: "The system is very busy when there are exams. That's why we sometimes start exams later and there is very little time left then. We can't finish all the questions."

P11: "I can't get help from the teacher when I have a question. If we were in the classroom, I would ask the teacher to answer my questions about the exam."

P17: "There are problems in online exams. Cheating becomes easier. The ones who study and do not study are not discriminated. Everyone gets high scores."

\section{Conclusion and Discussion}

Reducing the spread of the virus during the COVID-19 pandemic necessitated an abrupt transition from face-to-face education to distance education all across the world. In the face of this extraordinary situation, for which there is no specific deadline, distance education began to be used as the most readily available and reliable means to ensure the continuation of 
education. This unexpected abrupt change has led to the emergence of many problems in education. Identifying emerging shortcomings and problems and eliminating them will make distance education more efficient in the future. Thus, this current crisis may be turned into an opportunity by searching for ways to increase the effective use of distance education in the future. Learning a foreign language through distance education is more difficult (Hurd, 2006). In the light of this fact, this study examined the views of TFL students on distance education during the COVID-19 pandemic.

When the students' views were examined, the results demonstrated that students, learning Turkish as a foreign language, encountered many issues such as internet connection problems, lack of technological devices, problems arising from the system, and inability to focus on the online courses during their education. Internet access is an indispensable element of distance education. Examination of student responses showed that problematic internet connections and limited internet quotas were major problems. Other studies also reported weak internet connection and limited internet quota as the most important problems (Allo, 2020; Aryanti, 2020; Atmojo \& Nugruho, 2020; Efriana, 2021; Famularsih, 2020; Farrah \& Al-Bakry, 2020; Manibur Rahman, 2020; Öztürk Karataş \& Tuncer, 2020; Rahman, 2020; Tawhida, 2020; Tirtanawati, 2021). Dolmacı and Dolmacı (2020) conducted a study with foreign language educators and found that instructors too stated technical inadequacies and connection problems created problems in online courses. That some students did not have computers, tablets, and mobile phones to participate in distance education was also reported in the study. Similar problems were reported in other studies (Alan, Biçer \& Can, 2020; Aryanti, 2020; Efriana, 2021; Atmojo \& Nugruho, 2020; Farrah \& Al-Bakry, 2020;). It was also determined that the students did not fully understand the system used for distance education and experienced concentration problems regarding the classes.

The students stated that there was a lack of improvement in their Turkish proficiency levels due to the lack of practice in distance education, the challenges posed by distance education, and the problems regarding recall. Mahyoob's (2020) research revealed that students' lack of practice with teachers and classmates reduced their language levels. The studies conducted by Manibur Rahman (2020) and Farrah and Al-Bakry (2020) concluded that the students could not do practice due to the lack of opportunities for sufficient interaction. Students participating in Klimova's (2021) research also stated that distance education courses did not improve their English. The reasons for this were not regularly held classes, lack of practice, and technological difficulties experienced. In this respect, the results obtained in this study confirm the results of similar studies in the literature. Students who stated that they observed an improvement in their Turkish level in the distance education process stated that they watched Turkish TV series and movies, practiced whenever they had the opportunity, and adapted to distance education. It was observed that the courses alone were not enough to learn the language in the distance education process. It was concluded that the students who did individual work outside the classroom had improved their Turkish proficiency levels.

Examination of student views on the positive aspects of distance Turkish classes showed that protection from the pandemic, recorded lessons, gaining distance education experience, and saving time were regarded as positive aspects by the students. Güngör, Çangal and Demir (2020) also found that a comfortable learning environment, efficient use of time, easy access to classes, and maintaining social distance during the COVID-19 epidemic were reported as positive aspects of distance education by foreign students learning Turkish. Karatay, Kaya, and Başer (2021) stated that the advantages of distance education for foreign students learning Turkish were protection from contagious diseases, saving time, the opportunity to watch the 
lessons again, and reducing expenses. Allo (2020) and Aryanti (2020) examined the views of foreign language learners on remote access and pointed out that the learners regarded distance education as positive in preventing the spread of the virus. Manibur Rahman (2020) stated that students could listen to recorded lectures at appropriate times.

As for the negative aspects of online classes, the students reported a lack of practice, difficulty understanding the teaching point, being away from teachers and classmates, and inability to ask questions. Güngör et al. (2020) reported that foreign students learning Turkish expressed the negative aspects of distance Turkish lessons as lack of classroom interaction, technical problems, difficulty in homework control, and difficulty understanding the classes. Ustabulut's (2021) study revealed that the faculty members teaching Turkish as a foreign language through distance education stated that effective communication could not be provided in the lessons, that the students did not socialize, that technical problems were experienced, and that problems occurred in measurement and evaluation. Mahyoob (2020) and Manibur Rahman (2020) also concluded that the lack of language practice was a problem. In their study, Anca Maican and Cocoradă (2021) determined that students learning English as a foreign language in Romania experienced isolation and loneliness during distance education classes and missed face-to-face education activities. Famularsih (2020) also stated that the inability to establish direct communication between teachers and students during foreign language education and students' being unable to ask questions immediately about points they did not understand negatively affected classes. In the study by Eroğlu, Topal, and Özcan (2021), more than half of the instructors working in the field of teaching Turkish as a foreign language stated that they communicated well with students during distance education courses. The findings of other studies report similar results as well.

The students stated the positive aspects of distance education courses as viewing the recorded lessons repeatedly any time, saving time, and maintaining social distance during the pandemic. They reported limited practice opportunities, the feeling of isolation they experienced, and their inability to ask questions on the spot about issues they did not comprehend as the negative aspects of distance education courses.

When the views of the students who stated that their participation levels and motivation increased towards distance Turkish lessons were examined, it was found that teacher attitudes and their desire to learn were highly effective in that increase. Similarly, Allo (2020) reported that the learning aspirations of Indonesian EFL students had a positive impact on their participation in classes. In the study by Eroğlu, Topal, and Özcan (2021), it was seen that to increase the motivation of reluctant students, instructors benefited from online games, social media, music, and delegating responsibility to students during distance education lessons. Şengül (2021) stated that in teaching Turkish to foreigners through distance education, students' motivation decreased, and various methods, techniques, and activities such as social media, peer counseling, language partnership, online activities, and speaking club were used to increase students' motivation and interaction. Hurd (2006) found that motivation had a special and direct effect on distance language education. This shows that when students are motivated, they are more successful.

Some students stated that their participation levels and motivation decreased towards distance Turkish lessons. The analysis of the data showed that the feelings of loneliness and students' inability to concentrate on classes were generally important in the decline. Similarly, studies by Hernández and Flórez (2020) and Mahibur Rahman (2020) showed that students learning a foreign language experienced feelings of isolation and had problems focusing on classes. It is 
the very reason that why the students' participation in the course was low. In the study by Klimova (2021), students who stated that their motivation towards the course decreased expressed a lack of social contact, difficulty concentrating, and lack of time to answer questions as reasons.

Examination of students' views on the effect of distance Turkish education on reading skills showed that the reading skills of the majority of the students were positively affected. It was found that the students who reported an improvement in their reading skills had used their spare time by reading different kinds of books. It was also concluded that the students who reported no improvement in their reading levels had not practiced reading and spent a lot of time on the internet. Famularsih (2020) stated that the reading and writing skills of students who learned English as a foreign language through distance education improved more compared with other language skills. In this respect, the results of this study are similar to other studies on the subject.

The analysis of the students' views on the effect of distance Turkish education on listening skills showed that the listening skills of the majority of the students were positively affected. There was a high number of students who mentioned an improvement as a result of watching Turkish TV series and movies. The number of students who reported that in-class participation was also effective was very high as well. In the studies by Şengül (2021) and İskender (2021), the listening skill was shown as the skill that was least affected by negativities among other language skills and was the skill that was likely to improve. Some students declared that they saw no improvement in their listening levels and mentioned the lack of interaction with other people as their reason. This result is in line with the findings by Mahibur Rahman (2020) who observed that students were negatively affected by the lack of interaction opportunities. The study by Dolmaci and Dolmac1 (2020) reported that the participating foreign language educators also considered teaching listening skills through distance education as problematic and difficult like the students in other studies.

Although teaching listening through distance education is considered difficult, it was observed that the students' listening skills had improved through individual efforts outside the classroom. Learning the language through Turkish films and TV series instead of the classroom environment was influential on those efforts.

The students' views on the effect of distance Turkish education on writing skills showed that students had improved their writing skills through writing assignments, technological support, and extracurricular activities. Students who reported no improvement declared that they did not like writing and did not feel the need to write. Öztürk Karataş and Tuncer (2020) determined that writing was the skill that had more advantages in terms of teaching in the distance education process. They stated that writing could be developed at the highest level as it was used continuously in almost all assignments and projects. Famularsih (2020) stated that the reading and writing skills of students who learned English as a foreign language through distance education had improved more than other language skills. Mahibur Rahman (2020) and Şengül (2021) found that foreign language educators, not students, experienced difficulties in teaching writing.

The available studies in the literature point out that in distance education writing has taken the place of the most commonly used speaking skill used in face-to-face education. Considering that classes are carried out through writing as well as doing assignments, it is natural for the writing skill to develop more than other skills. Using computer programs that highlight the 
typing errors made during writing activities also significantly contributes to the development and improvement of the students' writing skills.

Student views on the effect of distance Turkish education on speaking showed that the speaking skills of the majority of the students were negatively affected. Students reporting no improvement in speaking mentioned that they could not converse with others due to isolation. Mahibur Rahman (2020) found that students did not have any opportunities for interaction as they were socially isolated. Öztürk Karataş and Tuncer (2020) determined that speaking was the most disadvantaged skill in distance education and was largely ignored. In Wang \& Zhang's (2021) study, it was determined that the skill that foreign language students experienced anxiety the most was the speaking skill. The students stated that the reason for this was the lack of a suitable environment for speaking and the feeling of loneliness. It was seen that the students felt comfortable speaking in educational environments created by their teachers during face-to-face education and that they preferred to remain silent in distance education lessons. This shows that distance education cannot provide students with the confidence and comfort provided by the conventional classroom environment. Hernández and Flórez (2020) revealed that foreign language learners experienced a constant feeling of isolation, resulting from a lack of interaction with their teachers and peers. Similar results were obtained in this study. It was also found that the students who reported an improvement in their speaking skills had interacted with other people whenever they had the opportunity.

The available studies in the literature showed that, in distance education, students failed to develop their speaking skills the most. Both students and instructors agreed that speaking skills did not develop at the desired level. The most important reason for this was the isolation people were living in due to the pandemic. Since students were not able to convene, they could not find opportunities to practice speaking. Consequently, the students' speaking skills did not develop at the desired level.

More than half of the students considered online exams to be negative experiences due to internet connection problems, bottlenecks in the system, cheating, and inability to ask teachers questions about exam parts they did not understand. Dolmac1 and Dolmac1 (2020) reported that foreign language educators regarded online exams as negative due to reasons such as technical problems emanating from the internet, technology, lack of supervision during the exams, inability to prevent cheating, and low exam reliability and objectivity. Farrah and Al-Bakry (2020) and Mahibur Rahman (2020) mentioned that students cheating in online exams bothered other students. Mahyoob (2020) determined that some students could not take the exams due to system failures and technological problems. Şengül (2021) stated that various problems occurred during online exams such as ethical problems, problems arising from the internet and technology, problems caused by students' not understanding the system used in examinations, problems arising from the validity of the exams, and problems arising from the extending of the exam period. In terms of the congruence of findings, this study and similar studies support each other. Not experiencing exam anxiety and the opportunity to be able to take the exams anywhere, on the other hand, were considered as the positive aspects of the online exams.

The following recommendations are offered based on the results of the research; online exams conducted to assess students' proficiency levels can be given in a more objective manner and can be supervised better. This way, cheating may be prevented, and successful and unsuccessful students may be more clearly identified. The reliability of online exams may thus be increased. Language learning platforms that may be used easily even by students who 
do not have sufficient knowledge, experience, and skills in technology may be created. To eliminate the feeling of loneliness experienced by students in distance education, activities may be carried out to ensure intensive teacher-student and student-student interaction as is the case in a face-to-face classroom environment. Language education aims to develop four language skills in learners. Therefore, activities that involve practicing those skills should be utilized, and various programs that include such activities may be designed to improve learners' basic language skills.

\section{References}

Ahmad, S. Z. (2016). The flipped classroom model to develop Egyptian EFL students' listening comprehension. English Language Teaching, 9(9), 166-178.

Alan, Y., Biçer, N., \& Can, F. (2020). Perspectives of pre-service teachers on distance education: covid-19 process. Revista Argentina de Clínica Psicológica, 29(5), 19721984.

Allo, M.D.G. (2020). Is the online learning good in the midst ofcovid-19 pandemic? The case of EFL learners. Journal Sinestesia, 10(1), 1-10.

Ariyanti, M. (2020). EFL students' challenges towards home learning policy during covid-19 outbreak. Indonesian Journal of English Language Teaching and Applied Linguistics, 5(1), 167-175.

Atmojo, A.E.P., \& Nugroho, A. (2020). EFL classes must go online! Teaching activities and challenges during covid-19 pandemic in Indonesia. Register Journal, 13(1), 49-76. DOI: https://doi.org/10.18326/rgt.v13i1.49-76

Büyüköztürk, Ş., Çakmak, K. E., Akgün, Ö. E., Karadeniz, Ş., \& Demirel, F. (2016). Bilimsel araştırma yöntemleri [Scientific research methods]. Ankara: Pegem Akademi.

Carrillo, C., \& Flores, M., A. (2020) Covid-19andteachereducation: a literature review of online teaching and learning practices, European Journal of Teacher Education, 43(4), 466-487, DOI: 10.1080/02619768.2020.1821184

Christensen, L. B., Johnson, R. B., \& Turner, L. A. (2015). Research methods, design, and analysis. UK: Pearson Education Limited

Cohen, L. Manion, L., \& Morrison, K. (2007). Research methods in education (6th ed.). New York, NY: Routledge.

Council of Higher Education (2020). Üniversitelerde uygulanacak uzaktan eğitime ilişkin açıklama. $\quad$ Retrieved from https://www.yok.gov.tr/Sayfalar/Haberler/2020/universitelerde-uygulanacak-uzaktanegitime-iliskin-aciklama.aspx

Creswell, J. W. (2013). Qualitative research methods. In qualitative inquiry and research design: choosing among five approaches. Ankara: Siyasal Bookstore.

Dabbagh, N., \& Brenda B. (2005). Online learning: Concepts, strategies, and application. Pearson.

Doğan, Y. (2020). Turkish university students' views on distance online foreign language learning. The Journal of Turkish Educational Sciences, 18(1), 483-504. https://doi.org/10.37217/tebd.655955

Dolmac1, M., \& Dolmac1, A. (2020). The views of lecturers in foreign language teaching via synchronous distance education: A Covid19 case. The Journal of Turkish Educational Sciences, 18(2), 706-732.

Efriana, L. (2021). Problems of online learning during covid-19 pandemic in EFL classroom and the solution. Journal of English Language Teaching and Literature, 2(1), 38-47.

Eroğlu, S., Topal, M. \& Özcan, E (2021). Opinions of teachers who teach Turkish as a foreign language on distance education: The case of Sakarya University TÖMER. RumeliDE 
Dil ve Edebiyat Araştırmalart Dergisi, (10), 461-479. DOI: 10.29000/rumelide.1012470.

Erzen, E., \&Ceylan, M. (2020). Covid-19 pandemic and distance education: problems in implementation. Ekev Academy Journal,24. 229-248.

Famularsih, S. (2020). Students' experiences in using online learningapplicationsduetocovid19 in English classroom. Studies in Learning and Teaching, 1(2), 112-121.

Farrah, M., \& Al-Bakry, G. H. (2020). Online learning for EFL students in Palestinian universities during corona pandemic: Advantages, challenges and solutions. Indonesian Journal of Learning and Instruction, 3(2), 65-78. DOI: https://doi.org/10.25134/ijli.v3i2.3677

Güngör, H., Çangal, Ö., \& Demir, T. (2020). The views of learners and instructors as to distant teaching Turkish as a foreign language. Gazi University Journal of Gazi Educational Faculty, 40(3), 1163-1191

Gürer, M. D. (2021). Açık ve uzaktan öğrenmenin temelleri [Foundations of open and distance education]. In Erkan Tekinarslan \& Melih Derya Gürer (Eds.) Açık ve uzaktan öğrenme [Open and distance education]. Ankara: Pegem Akademi

Hernández, S.S.F., \& Flórez, A.N.S. (2020). Online teaching during covid-19: how to maintain students motivated in an EFL class, Linguistics and Literature Review, 6(2), 157- 171. https://doi.org/10.32350/llr.62.14

İskender, M. E. (2021). Experiences of distance learning courses in teaching Turkish as a foreign language. RumeliDE Dil ve Edebiyat Araștırmaları Dergisi, (22), 96-117. DOI: 10.29000/rumelide.885523.

İşman, A. (2011). Öğretim teknolojileri ve material tasarımı [Instructional technologies and material development] (4. edition). Ankara: Pegem Akademi.

Karakış, Ö. (2020). The view of the relationship between university students' opinions about distance learning environments and English course success. Abant Izzet Baysal University Journal of Faculty of Education, 20(4), 1711-1728.

Karatay, H., Kaya, S. \& Başer, D. (2021). Student views on distance education in teaching Turkish as a foreign language. RumeliDE Dil ve Edebiyat Araştırmaları Dergisi, (24), 223-232. DOI: 10.29000/rumelide.995286.

Kaya, Z. (2002). Uzaktan eğitim [Distance education]. Ankara: Pegem A Yayınc1lık.

Keegan, D. (1996). The foundations of distance education. London: Croom Helm.

Kırık, A. M. (2014). Historical development of distance education and the situation in Turkey. Marmara University Journal of Communication, 21, 73-94.

Klimova, B. (2021). An insight into online foreign language learning and teaching in the era of COVID-19 pandemic. Procedia Computer Science, 192, 1787-1794

Mahibur Rahman, M. (2020). Challenges and solutions of teaching English as a foreign language online during a global pandemiclikecovid-19: Saudi EFL teachers' perspectives. Journal of Southwest Jiaotong University, 55(6), 1-9. DOI : 10.35741/issn.0258-2724.55.6.10

Maican, M.A. \& Cocoradă, E. (2021). Online foreign language learning in higher education and its correlates during the COVID-19 pandemic. Sustainability, 13, 781, 1-21, https://doi.org/10.3390/su13020781

Nenko, Y., Kybalna, N., \& Snisarenko, Y. (2020). The covid-19distance learning: insight from Ukrainian students. Revista Brasileira de Educação do Campo, 5, 8925-8925.

Özaygen, A. (2000). Internet-based distance education. Journal of Science and Technology, $388,100-103$ 
Öztürk Karataş, T., \& Tuncer, H. (2020). Sustaining language skills development of preservice EFL teachers despite the covid- 19 interruption: A case of emergency distance education. Sustainability, 12(19), 1-34, https://doi.org/10.3390/su12198188

Paker, T. (2017). Durum çalışması [Case study]. In Fatma Nevra Seggie \& Yasemin Bayyurt (Eds.), Nitel araştırma: Yöntem, teknik, analiz ve yaklaşımları [Qualitative research: method, technique, and approaches] (pp. 119-135). Ankara: Anı Yayınc1lık.

Payne, J.S. (2020). Developing L2 productive language skills online and the strategic use of instructional tools. Foreign Lang. Ann. 53, 243-249

Rahman, K. (2020). Learning amid crisis: EFL students' perception on online learning during covid-19 outbreak. Eternal,6(2), 179-194.

Şengül, K. (2021). Teaching Turkish a foreign language during the distance education process. RumeliDE Dil ve Edebiyat Araştırmaları Dergisi, (24), 174-222. DOI: 10.29000/rumelide.995482.

Tawhida, A. (2020). Problems and challenges faced by EFL students of Saudi Arabia during covid-19 pandemic. Rupkatha Journal on Interdisciplinary Studies in Humanities. 12(5), 1-7.

Tirtanawati, M.R. (2021). Virtual learning program in the midst of Covid-19 outbreak: EFL learners' perceptions. A Journal of English Language Teaching Linguistics and Literature, 4(1), 21-31.

Turkish Academy of Sciences, (2020). Covid-19 Pandemi Değerlendirme Raporu. Retrieved from http://www.tuba.gov.tr/files/images/2020/kovidraporu/Covid-19\%20RaporuFinal\%2B.pdf

Ustabulut, M.Y. (2021). SWOT analysis for the distance education process of lecturers teaching Turkish as a foreign language. Educational Policy Analysis and Strategic Research, 16(1), 139-152.

Uşun, S. (2006). Uzaktan eğitim [Distance education]. Ankara: Nobel Yayın Dağıtım.

Wang, X. \& Zhang, W. (2021). Psychological anxiety of college students' foreign language learning in online course. Frontiers Psychology, 12, 1-10. doi: 10.3389/fpsyg.2021.598992

Yalın, H. İ. (2003). Öğretim teknolojileri ve material geliştirme [Instructional technologies and material development] (8. Edition). Ankara: Nobel Yayınlar1.

Yanpar, T. (2009). Öğretim tasarımı ve materyal geliştirme [Instructional design and material development]. Ankara: Anı Yayınc1lık.

Yıldırım, A., \& Şimşek, H. (2016). Sosyal bilimlerde nitel araştırma yöntemleri [Qualitative research methods in social studies] (10. Edition). Ankara: Seçkin Yayıncılık. 